\title{
ПОИСК НОВОГО ПОКОЛЕНИЯ АНТИМИКРОБНЫХ АГЕНТОВ СРЕДИ НОВЫХ ПРОИЗВОДНЫХ АНТИБИОТИКОВ АМИНОГЛИКОЗИДОВ
}

\author{
К.С. Шаповалова ${ }^{1,2}$, А.Н. Тевяшова ${ }^{1,2}$ \\ ${ }^{1}$ ФГБНУ Научно-исследовательский институт по изысканию новых антибиотиков \\ им. Г.Ф. Гаузе, 119021, Россия, г. Москва, ул. Большая Пироговская д.11. \\ ${ }^{2}$ Российский химико-технологический университет им. Д.И. Менделеева, \\ 125047, Россия, г. Москва, Миусская пл., 9.
}

DOI: 10.19163/MedChemRussia2021-2021-374

E-mail: 79190328760@yandex.ru

Быстрое распространение антибиотикорезистентных штаммов во всем мире, а также наличие побочных эффектов, обуславливают актуальность поиска новых высокоэффективных противомикробных агентов. Одним из наиболее продуктивных подходов в этом направлении является химическая трансформация природных антибиотиков. В последние годы появилось новое направление модификации - создание конъюгатов с различными фармакофорными группами. Аминогликозидные антибиотики - один из первых открытых классов антибактериальных агентов, но, несмотря на это в настоящее время они переживают эпоху «ренессанса», поскольку имеют широкий спектр биологической активности, в частности, в отношении грамотрицательных бактерий и микобактерий.
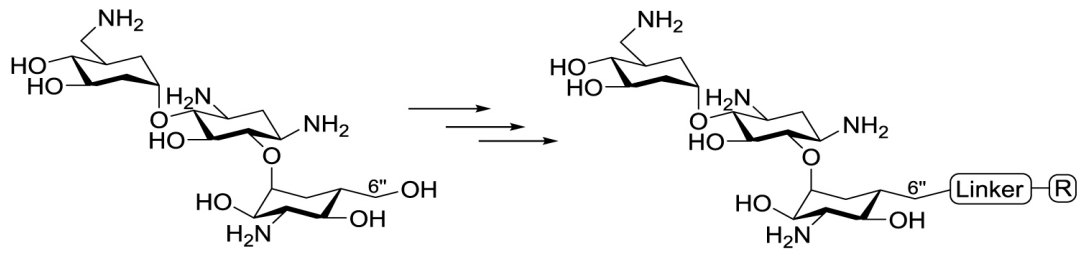

$\mathrm{R}=$ фармакофорная группа

Целью работы являлся синтез конъюгатов канамицина А, содержащих фармакофорную группу, присоединенную через линкер в положении 6". Синтез новых производных осуществлён в 5 стадий - на первом этапе блокировали аминогруппы канамицина А защитными группами уретанового типа, с последующей заменой 6"-гидроксигруппы на легко уходящую триизопропилбензилсульфокислотную группу. Далее введило диаминовый линкер в положение 6"-канамицина А и поводили взаимодействие с фармакофорами содержащими кислотную группу, т.е. способными ацилировать полученный на предыдущей стадии интермедиат. На последней стадии проведено удаление защитных групп для получения целевых производных канамицина А. Биологическую активность новых полусинтетических антибиотиков планируется изучить на различных моделях. 